\title{
Femininity in The Strange Case of Dr. Jekyll and Mr. Hyde
}

\author{
Cao Shuo \\ School of Foreign Languages, Dalian University of Technology, China \\ No.2 Linggong Road, Ganjingzi District, Dalian, Liaoning Province, China, 116024 \\ E-mail: mollycao1977@gmail.com \\ Liu Dan \\ School of English Studies, Dalian University of Foreign Languages, China \\ 6 Xiduan, Lvshun Nanlu, Lvshun, Dalian, Liaoning Province, China, 116044 \\ E-mail: doreen_ld@163.com
}

Received: November 14, 2011

Accepted: December 21, 2011

Published: March 1, 2012

doi:10.5539/ells.v2n1p123

URL: http://dx.doi.org/10.5539/ells.v2n1p123

\begin{abstract}
This paper, based on Robert Louis Stevenson's life and social experience, explores the femininity in The Strange Case of Dr. Jekyll and Mr. Hyde. Critical moments of feminine quality in this male- centered story are identified through the roles that female charactres play as (1) humble counterpart to males in socio-cultural context, (2) feminine energy in sex and sexuality in the gender context and (3) object of the Oedipus complex in the familial context. It is pointed that Stevenson designed femininity in male characters and interchangeability between two genders. The novel can therefore be seen as a story offering readers a panoramic view in which Stevenson's Victorian female world, his concerns about gender issues, and his standpoints of human nature are all well presented.
\end{abstract}

Keywords: Femininity, The Strange Case of Dr. Jekyll and Mr. Hyde, Men, Women, the Victorian Period

\section{Introduction}

Robert Louis Stevenson's masterpiece story, titled with The Strange Case of Dr. Jekyll and Mr. Hyde, has many claims. It centers upon a conception of humanity as dual in nature, right and wrong, joy and despair, good and evil. It employs intertwined narrative techniques, like flash- back, foreshadowing and suspense. It invites readers to question the value system of the late Victorian period about temperance.

For many critics, the non- appearance of women in this novel as equals or intimates to the main characters, is a literary outcome of Stevenson's life and social cultural experience. An interpretation is that Strange Case of Dr. Jekyll and Mr. Hyde dramatizes the inherent weakness of late- Victorian social organization, a weakness that derives from unsolved, pre-oedipal and oedipal emotions and that threatens the very possibility of the community (Doane, 1989). William Veeder (1988), in Children of the Night: Stevenson and Patriarchy insists that the men in the story create a close- knit society that "replicate[s] ...mother-child mirroring" (p.45). Men mirror each other--- their bonds are homosocial and homoerotic--- and so avoid a feared relationship with peer- aged woman. But dichotomy is ubiquitous, as Stevenson says in his work that "man is not truly one, but truly two" (Stevenson, p.48). This novel is no exception to the gender problems of the time. Though it was a book intended for young male readers, Stevenson would have never been able to explain men's issues without dealing with a sort of interactive relationship between men and women. The male- centered community's repression of its female counterpart only increases the fascination of it. Jennifer Beauvais (2009) in her dissertation identified a blurring sphere between female characters and male characters by claiming that "the domesticated man moves from the 'maculinized' public sphere into the 'feminized' private sphere, by engaging in feminine discourse including issues of domesticity, chastity, morality, marriage, and love".

To re-affirm that femininity was deeply probed instead of being alienated in the novel, I follow the three functions of females which could be found in the late Victorian Period: a humble counterpart to males in socio-cultural context, feminine energy in sex and sexuality in the gender context and the object of the Oedipus Complex in the familial context, with an aims to explore critical moments in this male- centered story when feminine elements are expressed 
in an ambiguous or subtle manner, that a bibliographical and socio-cultural interpretation can be achieved that this novel is a vivid reflection of the gender issue of both the writer himself and his time.

\section{Humble Counterpart to Males in Socio-cultural Context}

As far as the plot is concerned, in the community of celibates Stevenson created, none of the male characters has the slightest relationship with a female friend or relative. The few female characters appear only ephemerally and their names and background remain mysterious to readers: a little girl from a poor family whom Hyde knocks down and tramples when their paths cross at the intersection, a few of her indignant female relatives, the maid who observes Jekyll's murder of Sir Danver Carew, Hyde's Soho landlady, the cook and maids in Jekyll's household, and a woman selling matches on the street. More importantly, I argue that the general absence of women (and concomitantly the absence of violence against them) as their "negation," which can be seen as a form of violence. It can basically offer a panoramic view of the Victorian females in a socio-cultural context. All these female characters are of low social status and seem to be designed to be submissive to men and give an implication of their impersonality. Stevenson explicitly keeps women in the margins of both the story and the society, which enables his book to conform to his social norm and to represent his social conflict.

Placed in a vulnerable economic and social position, the status of women in the Victorian Era is taken as an illustration of the striking discrepancy between England's national power and wealth and what many, then and now, consider its appalling social conditions. "Nineteenth-century religious beliefs encouraged women's subordination and, therefore, contributed to both societal and domestic assault. These principles often led men to justify their right to use violence to control their female counterpart" (Hammerton, 1992, p.43). The Victorian period was a time of great religious following. People during the nineteenth-century believed that the "Bible supported women's submission and often used biblical quotes to defend such claims" (Glenn, 1984, p.65). This emphasis of religious subordination suggested that, for a woman to be virtuous and serve God, she must follow the lead of men. In addition, this gave men the impression that they had a God- given right to control women, even if this meant a correction through physical violence.

In the novel, "hellish" violence is obvious against the unnamed (female) "child" as "a central Victorian male investment in and fixation of the female (female without the woman, a ruly body, without trouble for men)" (Cohen, 2004).

One little man who was stumping along eastward at a good walk, and the other girl of maybe eight or ten who was running as hard as she was able down a cross street. ...the two ran into another naturally enough...the man trampled calmly over the child's body and left her screaming on the ground. (9)

Close readers would question "why did the scene happen in the intersection?" and "why was the girl running as hard as she was able?" I make no claim that Stevenson is conscious of all these significance. What I do claim is that diverse elements coherently support his indictment of late- Victorian female repression. The late Victorian period is a transitional era and eventful with movements like women suffrage. So the intersection is symbolic historically. The girl, due to the discrepancy of gender power, seems trying to avoid conflict with Hyde by running as hard as she could. The diction of Enfield witnessing this scene insisted that Hyde was "at a good walk" and that the clash was "natural". This helps prove the solidarity of men. Even when Hyde tramples over the girl "calmly", Enfield thinks that "it sounds nothing to hear" (8), but the truth is that the girl is screaming. Male authority allows for him to use violence, if necessary, in order to keep her in line (Glenn, 1984). The violent scene, in some way, serves as a vivid display of both physical and spiritual repression upon the Victorian women. The violence inherent in such exclusion of woman bursts forth when Edward Hyde is roaming the night streets. "Once a woman spoke to him, offering, I think, a box of lights. He smote her in the face, and she fled" (94). Since Jekyll remembers all the other particulars of his day as Hyde, why is he unsure what the woman offered Hyde? A woman who walks the streets late at night asking men if they need a light is offering quite another type of box. And Jekyll knows it. Jekyll does not want to admit that the violence of Hyde's response is directed against female sexuality, for such an admission would confirm misogyny too starkly. But the point is that the more he wants to hide the misogyny, the more it is exposed and the more submissive Victorian women are displayed. Women suffer from men's abusive power.

How the maid witnessing Hyde's killing Canver is presented is equally impressive for male- chauvinism. "[The maid] sat down upon her box, which stood immediately under the window, and fell into a dream of musing. Never had she felt more at peace with all men or thought more kindly of the world" (21). Readerly interpretations might focus on the implications that only at late night can the maid feel at ease, only under the window from where can she observe the outside world, and only distancing her from the two men can she experience no hurt and witness the crime so that the plot can move on. Women's alienation from the normal main- stream Victorian life is self- evident. The description of Hyde's landlady was also not pleasant. "An ivory- faced and silvery- haired old woman opened the door. She had an evil face, smoothed by hypocrisy..." (23). All the female characters are pitiful, shabby- looking 
and submissive to men in the novel.

As it has been suggested that "Stevenson was working as he did under Victorian restrictions and not wishing to bring colors into the story alien to its monkish pattern, consciously refrained from placing a pained feminine mask upon the secret pleasures in which Jekyll indulged" (Nabokov, 1980, p.194), females are holding an inferior position to their male counterparts, a highly- reputed doctor and well- respected lawyer.

\section{Feminine Energy in Sex and Sexuality in Gender Context}

Duality is what Stevenson wants to explore in this novel, and it is obvious that a story without important women would have never been consistent with the theme of duality or powerful to support it. On the other hand, Stevenson married Fanny, a woman much older than him. Some scholars argue that he has Oedipus Complex. As Kanzer and Fiedler (1988) have maintained, "Stevenson is a man torn by oedipal emotions...by not waiting for confrontation with the father, he preludes therapeutic working through of oedipal emotions..." (p.111). All this renders a possibility that he would have taken sex and sexuality into consideration for his works. In the sex and sexuality relationship in the novella, the feminine energy is displayed by feminized men.

Stevenson textually establishes collaboration between the masculine and feminine that subverts the identity of each, which presents an implicitly sensual sexual relationship. Jekyll, the most superior male character, professionally distinguished, fifty- year-old conservative bachelor, always socializes with the same aged male peers. Having no access to a wife, girlfriend, or fiancée, Jekyll has from an early stage of his life indulged in night- time pleasures that he finds uncomfortably inconsistent with his cherished public image of himself. Yet we never learn exactly what those secret nocturnal pleasures are. Stevenson merely writes that a "certain impatient gaiety of disposition" (47) and speaks of those pleasures as being "to say the least, undignified" (48). What he means gives an implication of sex and sexuality. The role that women play in sex and sexuality is to represent feminine energy. In a case of no appearance of important female characters and no direct involvement with the males in the story, Stevenson employs role shifting between men and women and creates a flexibly-changing bisexual environment, which can be recognized as the transformative power between men and women that are presented through masculinity in female characters and femininity in male characters.

Readers can detect that this story includes a number of minor female characters who are monstrous and deviant: the little girl improbably at large in the night; the women "wild as harpies" who attack Hyde; the old woman with "an evil face, smoothed by hypocrisy." Compared with these females, males with feminine quality are also powerfully depicted. Because the maleness of the story's world is evident: Jekyll and Hyde, of course, and also "Utterson the lawyer" whose portrait opens the first chapter and Mr. Richard Enfield, his distant kinsman, the "well- known man about the town", and also Utterson and Jekyll's friend "the great Dr Lanyon"; these are the principals, the story's narrators and actors--- two doctors, a lawyer, a man about the town, and then Hyde, "the fiend". None of them in the story has anything to do with women and there are no equal women: Jekyll has had "pleasures" and been guilty of "irregularities" but has no wife; Hyde has lodgings in Soho but we know only the incidents already mentioned; Utterson lives in 'his bachelor house' and Enfield and Lanyon too are apparently celibates. But feminine qualities can be recognized in these bachelors. To some readers, Hyde resembles a lady "weeping like a woman or a lost soul" (16), "so much smaller, slighter and younger" (51) stature, "knit to Jekyll closer than a wife" (61) and called Jekyll's "favorite" (48). Jekyll and Hyde are like two lovers in the laboratory where "there lay the cabinet their eyes in the quiet light, a good fire glowing and chattering on the hearth, the kettle singing its thin strain, ... and nearer the fire, the things laid out for tea; the quietest room one would have said..."(39).

Utterson, whose name is weird to combine "utter" and "son" (which means giving birth to a baby) or udder son (breast son), is another representative of male characters embodying female qualities. In many instances in the novella, Utterson, true to his Victorian society, adamantly wishes not only to preserve Jekyll's reputation but also to preserve the appearance of order and decorum. He definitely is reminiscent of a bossy motherly figure, trying to put everything under her control. In the novel, Utterson, time and time again, plays a role of woman in a homoerotic relationship. At the beginning of the novel, readers can feel a sort of homoerotic atmosphere surrounding Utterson and Enfield.

No doubt, the bond that united him to Mr. Richard Enfield, his distant kinsman, the well- known man bout town. It was a nut to crack for many, what these two could see in each other or what subject they could find in common. It was reported by those who encountered them in their Sunday walks, that they said nothing, looked singularly dull, and would hail with obvious relief the appearance of a friend. For all that, the two men put the greatest store by these excursions, counted them the chief jewel of each week, and not only set aside occasions of pleasure, but even resisted the calls of business, that they might enjoy them uninterrupted (8).

What I am left with is that Utterson and Enfield, like two lovers, are shopping for beautiful jewelry in carefree manner. Completely into it, they even ignore the call of business. This, in some sense, is what later shades into "a 
connotation of "homoerotic"' (Veeder, 1988, p.144). Late- Victorian professional men feel emotions that they can neither express nor comprehend. An aura of homosexuality serves to signal both the homoerotic nature of many male bonds and the lethal consequences of them.

He (Utterson) sat on one side of his own hearth, with Mr. Guest, his head clerk, upon the other, and midway between them, at a nicely calculated distance from the fire, a bottle of a particular old wine. The room was gay with firelight. In the bottom the acids were long ago resolved; the imperial dye had so softened with time, as the color grows richer in stained windows; and the glow of hot autumn afternoons on hillside vineyards was ready to be set free and to disperse the fogs of London. Insensibly the lawyer melted (53-54).

Granted that on one level a tender human friendship exists between these men: friendship cannot account for all the details, the agents of affect, that appear in the scene. Why, for example, in a scene that ostensibly is pure plot contrivance--- a handwriting expert is brought in to examine Hyde's script and, with supreme convenience, is presented with Jekyll's as well--- are there so many layers of literary materials? "The melting mood" is one of Victorian fiction's conventional expressions for emotional surrender, but I have never seen the expression applied to man. Utterson melts in a scene almost parodic of conventional seduction--- the irresistible male guest, the cozy warmth of the night privacy, the lubricating bottle of wine, the dictions like "gay" and "melt", all contribute to a sort of sensuousity in this scene.

Maybe I am going too far in groping for what Stevenson was not attempting to attain in his novel, but there is a fact, an undeniable fact, that the interchangeability between man and woman as well as the sensuous setting description renders an atmosphere, both romantic and mysterious, very suitable for the story plot and theme development. In addition, reading responses to the text itself help readers come up with diverse interpretations. To most readers, the novel centers on good and evil. Evil comes from original sins which include lust. The story seems to convey that sex and sexuality is everywhere, and human nature is at the risk of being threatened by sexual dislocations, which can powerfully support Jekyll's (he is a spokesman of all human beings) dreaming for years of creating a physical alter ego to free himself from his own pangs of remorse as well as from the possibility of detection.

\section{Object of Oedipus Complex}

Oedipal conflict is not obvious on the plot level of Jekyll and Hyde, where no father or mothers appear. I will begin with one passage that seems to me central to Stevenson's view of parent- child relations.

"Today in Glasgow my father went off on some business, and my mother and I wandered about for two hours. We had lunch together, and were very merry over what people at the restaurant would think of us--- mother and son they would not have supposed us to be" (Cooper, 1948, p.53). Louis is thus capable of seeing mother as object of desire, and of imaging himself dispatching as a rival "patriarch". As a matter of fact, Louis and Thomas Stevenson depict hostility in shockingly lethal terms. Thomas, who informs Louis that "you have rendered my whole life a failure....I would ten times sooner see you lying in your grave than that you should be shaking the faith of other young men" (Bloom, 2005, p.332). Louis reciprocates. "I say, my dear friend, I am killing my father--- he told me tonight that I have alienated utterly my mother" (Linehan, 2003, p. 80). The last half of this sentence is as important as the first. Killing the father is counterproductive because the more the son fights for mother, the more she sides against him. Louis recognizes the inevitability of father- son conflict. Stevenson can be seen as a writer who has a strong Oedipus complex. Freud argues that desire, which is directed toward the mother initially and is interdicted at the oedipal moment, can reappear under the pressures of adolescence--- in its initial triangular configuration. The mother is again the object of desire, and the father again the rival. In this novel, there are a few scenes in which the Oedipus Complex are displayed when femaleness is expressed through both female characters and feminized male characters, a result from Stevenson's unresolved ambivalences toward mother. So in some sense, to borrow Linehan's sentence, the absence of women from the plot as sex objects may be less of a clue to Hyde's violent nature than their absence as love objects in the frame work of Oedipus Complex (Linehan, 2003, p. 205).

First, it is suggested by the maid's positioning who witnesses Hyde's murder of Sir Danvers Carew. With the woman up at the second floor window, the two men approach from opposite ends of the street and stop "within speech" (46). The three figures form a triangle. The woman at the apex, the contending males squared off along the base: it is the classic oedipal configuration. Positioning her upon her box at the open window emphasizes her sexuality and availability.

Another Oedipus Complex occurs when Utterson is gong to break into Jekyll's lab with the help of Poole. Hyde, as a female character, is the hunted object of both Jekyll (father) and Utterson (son). Utterson now, through his surrogate Poole, is directing against Jekyll the oedipal vengeance.

Poole swung the axe over his shoulder; the blow shook the building, and the red baize door leaped against the lock and hinges. A dismal screech, as of mere animal terror, rang from the cabinet. Up went the axe again, and again the panels crashed and the frame bounded; four times the blow fell; but the wood was tough and the fittings were of 
excellent workmanship; and it was not until the fifth, that the lock burst in sunder, and the wreck of the door fell inwards upon the carpet (69).

This moment echoes the murder of Carew. As the murder weapon was of "tough and heavy wood" (47), the door's "wood was tough"; as Carew's beaten "body jumped upon the roadway" (47), the beaten "frame bounded"; as Carew's "bones were audibly shattered," the "panels crashed" (47). Utterson is acting out that oedipal rage for Stevenson.

When sex and sexuality is considered as sinful behavior that should be ambiguously and carefully dealt with, then the Oedipus Complex is a more sensitive issue. Based on the shift between gender identity, Stevenson moves on, boldly and skillfully, and penetrates the more sinful sexuality in human nature by establishing some triangle configurations, which also reveals that Stevenson integrates in his novella a level of himself. From this sense, he can be regarded as a supporter of the social norm of Victorian Period by phasing out female characters and, at the same time, also as a resister of his time by infusing into his work incestuous elements.

\section{Conclusions}

Stevenson seems to have gone to some trouble to exclude sex from his story textually. In part this might be due to his acute sense of what the market would bear--- Stevenson had no desire to write a story that would be considered as obscene or inappropriate for young readers. However, a literary work does not exist in a cultural vacuum. In late Victorian culture, "it was hard to place the feminine because women were quite literally on the move, invading and appropriating male prerogatives and discourse" (Doane, 1989, p.68). Therefore, the societal transformation opens up more interpretations on woman issues or feminine issues in literary works. Robert Louis Stevenson's great strength was that he never reduced the particular to the general, but struggled to articulate human circumstances in all their varieties and contradictions. Men are said to have feminine perceptions; women are masculine and direct. Written at a time when gender roles were shifting, the story accordingly lacks coherent representations of sexuality which, on the contrary, is represented in a discursive form and in a subtle fashion. The novel is not only a male society story, but is universal to both genders with a truth that human has a dual identity of good and evil. Stevenson included both genders into the quest and his special treatment of textual disappearance and between- line appearances of women help support the theme of duplicity. What's more, no matter what category a woman is located, as a humble counterpart to men, as feminine energy in a sexual relationship or as the object of the Oedipus Complex, she must be suffering pains both physically and psycho spiritually, which readers can identify with Hyde who undergoes "the infliction of pain." (196). Accordingly, on the plot level, character level, characterization level and setting level, Strange Case of Dr. Jekyll and Mr. Hyde is a story offering readers a panoramic view in which his Victorian female world, his concerns about gender issues, his standpoints of human nature are all well presented.

\section{References}

Bloom, Harold. (2005). Robert Louis Stevenson, 1850-1894 - Criticism and Interpretation. Philadelphia: Chelsea House.

Butler, Lisa. That damned old business of the war in the members: The Discourse of (In) Temperance in Robert Louis Stevenson's The Strange Case of $\mathrm{Dr}$ Jekyll and $\mathrm{Mr}$ Hyde. [Online] Available: http://www.synergiescanada.org/journals/erudit/ron25/ron1433/014000ar

Cohen, ED. Hyding the Subject?: The Antinomies of Masculinity in The Strange Case of Dr. Jekyll and Mr. Hyde. Novel, Fall/Spring 2003/2004, 37(1-2), 181-199. http://dx.doi.org/10.1215/ddnov.037010181

Cooper, Lettice. (1948). Robert Louis Stevenson. Chicago: Allan Swallow Company.

Doane Janice, \& Devon Hodges. Demonic Disturbances of Sexual Identity: The Strange Case of Dr. Jekyll and Mr. Hyde. A forum on fiction, 23, 1989, 63-74

Glenn, Myra C. (1984). Campaigns Against Corporal Punishment. New York: State University of New York Press. Hammerton, A. James. (1992). Cruelty and Companionship. London: Routledge.

Heath, Stephen. Psychopathia Sexualis: Stevenson's Strange Case. Critical Quarterly, 28, 1986, 93-108. http://dx.doi.org/10.1111/j.1467-8705.1986.tb00010.x

Linehan, Katherine. (2003). Sex, Secrecy, and Self- Alienation in Strange Case of Dr. Jekyll and Mr. Hyde. The Strange Case of Dr. Jekyll and Mr. Hyde, Lectures on Literature. New York: Norton Company.

Nabokov, Vladimir. (1980). The Strange Case of Dr. Jekyll and Mr. Hyde, Lectures on Literature. New York: HBJ.

Stevenson, Robert Louis. (2003). Strange Case of Dr. Jekyll and Mr. Hyde. New York: Norton Company.

Veeder, William, \& Gordon Hirsch. (1988). Dr. Jekyll and Mr. Hyde After One Hundred Years. Chicago: Chicago UP. 